\title{
Temperate facultative cleaner wrasses selectively remove ectoparasites from their client-fish in the Azores
}

\author{
Pauline Narvaez ${ }^{1}$, Miguel Furtado ${ }^{2}$, Ana I. Neto ${ }^{3,4}$, Isadora Moniz ${ }^{3,4}$, \\ José M. N. Azevedo ${ }^{3,4}$, Marta C. Soares ${ }^{1, *}$ \\ ${ }^{1}$ CIBIO, Centro de Investigação em Biodiversidade e Recursos Genéticos, Campus Agrário de Vairão, 4485-661 Vairão, \\ Portugal \\ ${ }^{2}$ Departamento de Biologia Animal, Universidade de Lisboa, Faculdade de Ciências, Campo Grande, 1746-016 Lisboa, \\ Portugal \\ ${ }^{3}$ Centro Interdisciplinar de Investigação Marinha e Ambiental (CIIMAR/CIMAR), Universidade do Porto, \\ Rua dos Bragas 289, 4050-123 Porto, Portugal \\ ${ }^{4}$ CIRN \& Departamento de Biologia, Universidade dos Açores, 9501-801 Ponta Delgada, Portugal
}

\begin{abstract}
Cleaner fishes are key contributors to the health of fish communities. However, much of the information in the literature refers to tropical systems, while fewer studies have examined the activity of cleaner fish inhabiting temperate ecosystems. Facultative cleaner fish are assumed to clean only during their juvenile phase, and have a broader diet than obligatory cleaner fish. Here, we focused on 2 facultative cleaner fish species, Coris julis and Thalassoma pavo, that live along the temperate coasts of the Azorean island of São Miguel. We found that these species focused their cleaning activities on relatively few species of clients, which supports the general idea that facultative cleaner fishes in temperate waters are less dependent on cleaning interactions than obligatory cleaner fishes in tropical waters. Both cleaner species were found to give more bites per host when inspecting larger clients, likely because the latter typically host more parasites. We found that $C$. julis consumed a greater diversity of food items, which included gnathiid larvae and fewer caligid copepods, compared to T. pavo where no ectoparasites were found. All cleaner fish that we collected after observations of cleaning had eaten gnathiid isopod larvae but not caligid copepods, even though caligid copepods were the most abundant ectoparasite found on the body of 7 selected fish species (including both client and non-client species), suggesting that both species selectively feed on gnathiid isopods. This study is the first to demonstrate that temperate facultative cleaner fish species actively and selectively inspect and remove ectoparasites from their client-fish species.
\end{abstract}

KEY WORDS: Temperate ecosystems · Cleaning mutualisms · Facultative cleaner fish · Coris julis . Thalassoma pavo $\cdot$ Stomach contents $\cdot$ Ectoparasites

Resale or republication not permitted without written consent of the publisher

\section{INTRODUCTION}

Marine cleaning symbiosis has long been a textbook example of mutualistic cooperation (Cushman \& Beattie 1991). Cleaners are usually small fishes or shrimps that inspect the body surface, gill chambers and mouth of other fish (known as clients) in search of ectoparasites, mucus and dead or diseased tissue (Côté 2000, Côté \& Soares 2011). These cleaner fish live in specific territories (referred to as cleaning stations), which clients actively visit and adopt a characteristic incitation pose, signalling their wish to be inspected. Cleaners then swim out to inspect the clients and glean material from their body surface. 
Cleaning stations are often visited by many residential fishes, but also by other organisms such as turtles, iguanas or even whales (Côté 2000).

More than 100 marine fish species engage in cleaning activities directed at other species of fish (Van Tassell et al. 1994, Côté 2000). The majority of these species are members of the families Labridae and Gobiidae, live in tropical habitats, and may exhibit a high degree of specialisation (Côté 2000). The best known obligatory cleaner species (i.e. those that clean throughout their lives, solely depending on food items obtained from the body surface of other species; Francini-Filho \& Sazima 2008) are the Indo-Pacific bluestreak cleaner wrasse Labroides dimidiatus (Randall et al. 1990) and the Caribbean sharknose cleaning goby Elacatinus evelynae (Côté \& Soares 2011). In temperate waters, and more specifically in the northeastern Atlantic, the rock cook wrasse Centrolabrus exoletus (Galeote \& Otero 1998) is an important cleaner species (Arnal \& Morand 2001) that is defined as facultative, i.e. clean only part-time or only during their juvenile phase (Limbaugh 1961) and tend to be less dependent on parasitic items than obligatory cleaners as they usually have a more varied diet (Côté 2000). The relative absence of obligatory cleaner species in temperate waters may be related to environmental conditions, which are generally less favourable for the development of parasites than tropical waters, and may consequently reduce the benefit of these interactions (Ayling \& Grace 1971). Nevertheless, behavioural studies on facultative cleaner fish activities and their parasitic dependency are very limited.

Marked differences exist among cleaner species when it comes to interspecific behaviour, which is usually determined by a species' diet preferences. For example, clients of the cleaner wrasse $L$. dimidiatus, which prefers to eat mucus instead of parasites (a cleaning behaviour referred to as 'cheating') usually react to cheating with whole body shudders known as jolts (Grutter \& Bshary 2003, Soares et al. 2008). In contrast, the broadstripe cleaning goby Elacatinus prochilos prefers to eat ectoparasites instead of client mucus (Soares et al. 2010). This means that the clients of $L$. dimidiatus need to enforce good levels of cooperative behaviour by punishing or by switching between cleaners (Bshary \& Grutter 2005). Thus, differences in cleaner fish food preferences and diet together with different levels of client parasite infestation seem to be prerequisites for the development of alternative behavioural strategies for cleaners and clients (Soares et al. 2013), and are responsible for subsequent changes in the beneficial outcomes of these interactions.
Cleaners and parasites interact within a predatorprey framework (Grutter 2002). Cleaners have a potential key role in lowering the parasite levels of their clients, and as a consequence contribute to a reduction in the negative effects of these parasites (Grutter \& Lester 2002). Indeed, ectoparasite infestation can affect the physiology, behaviour and morphology of hosts (Bunkley-Williams \& Williams 1998, Binning et al. 2013). The negative effects to fish may be quite significant; for instance by reducing swimming abilities, decreasing growth rates (Barber et al. 2000) or altering immunocompetence and basal cortisol levels (Ros et al. 2011). Therefore, at a larger scale, by significantly influencing the activities of client fish, cleaners can affect the structure of fish communities (Waldie et al. 2011).

Coris julis and Thalassoma pavo are both members of the Family Labridae and are protogynous hermaphrodites, i.e. individuals that first breed as females and eventually change sex to become male harem owners (Guidetti \& D'Ambrosio 2004). These species can grow to 30 and $25 \mathrm{~cm}$ respectively (Quignard \& Pras 1986, Schneider 1990). All individual C. julis $>18 \mathrm{~cm}$ in length are males (Muus \& Nielsen 1999), while for $T$. pavo, a length of $18 \mathrm{~cm}$ already represents a male in terminal sexual phase (Guidetti 2001). Juveniles and females of both species live in groups, while the males are normally solitary or found in small groups (Porteiro et al. 1996). C. julis and $T$. pavo were reported as cleaners for the first time by Moosleitner (1980) in the Mediterranean Sea. The first record of these cleaner fish species' activities in Macaronesia was made by Van Tassell et al. (1994). Further studies also referred to juveniles of C. julis and T. pavo as supplementary cleaners in the Mediterranean, particularly when the main cleaner species Symphodus melanocercus was relatively rare (Zander \& Sötje 2002, Fischer et al. 2007). The first and only report of cleaning interactions between $C$. julis and clients in the Azores archipelago was recently made by Bertoncini et al. (2009). Nevertheless, current knowledge on these temperate cleaner fish species' activities remains very limited, especially when compared with the amount of information collected on obligatory cleaner species.

In this study, we investigated the cleaning behaviour of the facultative cleaners C. julis and T. pavo in the Azores, by (1) recording their cleaning behaviour at 20 cleaning stations, (2) examining stomach contents to determine whether the cleaners truly removed parasites, and (3) inspecting the ectoparasite load of selected fish species from the Azorean coastal communities (some acting more frequently as clients 


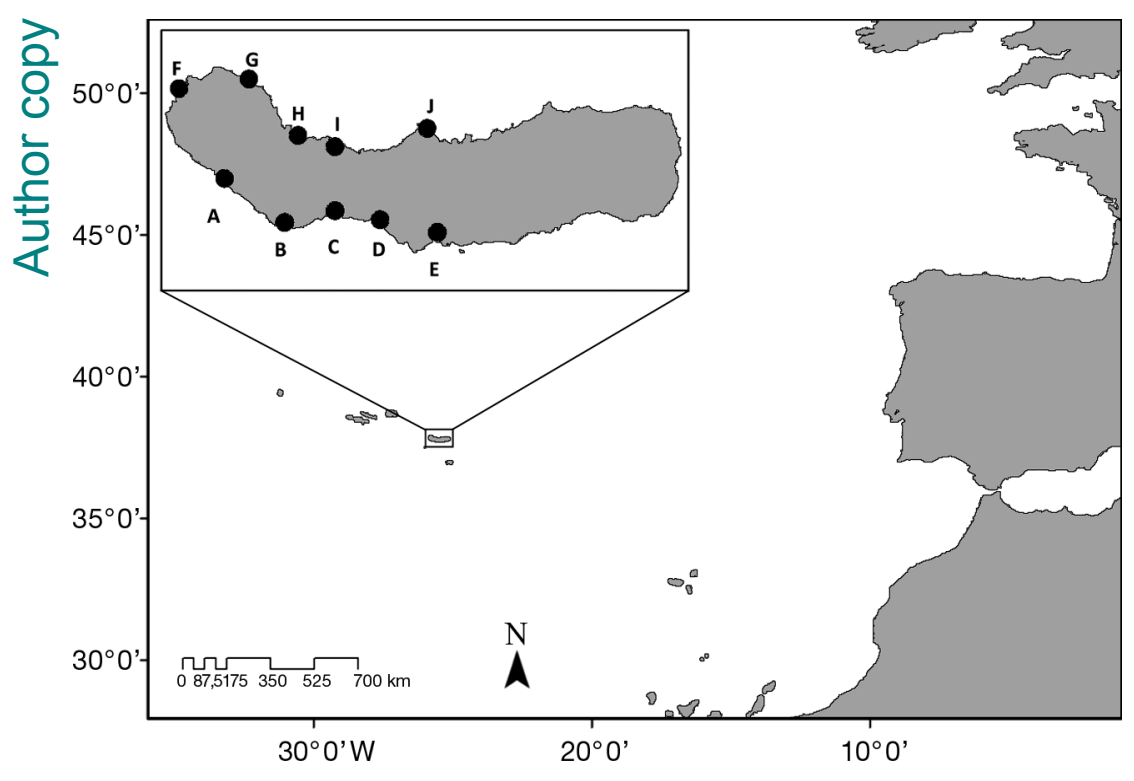

Fig. 1. Field locations around the island of São Miguel (Azores Archipelago): (A) Feteiras, (B) Ponta Delgada, (C) São Roque, (D) Lagoa, (E) Agua d'Alto, (F) Mosteiros, (G) Santo Antonio, (H) Capelas, (I) Calhetas, (J) Santa Iria

than others) to evaluate the effects of the cleaner fishes' activities on their parasite loads.

\section{MATERIALS AND METHODS}

\section{Study sites and species}

The 2 species investigated, Coris julis and Thalassoma pavo, are common on shallow rocky reefs around all the Azores islands (Bertoncini et al. 2010). This study was carried out between October 2012 and July 2013 on rocky reefs adjacent to São Miguel Island $\left(37^{\circ} 44^{\prime} 58^{\prime \prime} \mathrm{N}, 25^{\circ} 39^{\prime} 54^{\prime \prime} \mathrm{W}\right)$ (Fig. 1). Field sampling was done by snorkelling at depths varying between 1 and $5 \mathrm{~m}$. Behavioural observations were conducted at cleaning stations, which were normally located in small rocky depressions. The rocky substrates surrounding these cleaning stations were mainly covered with frondose algae (the most frequent were Asparagopsis spp., Halopteris spp. and Dictyota spp.).

\section{Behavioural observations}

Observations of 20 cleaning stations $(C$. julis $\mathrm{n}=10$ and $T$. pavo $\mathrm{n}=10$ ) were carried out between 14:00 and 16:00 $\mathrm{h}$ by snorkelling (Fig. 1, Site I). Only cleaning stations with a single cleaner fish (either C. julis or T. pavo) displaying juvenile colour patterns were selected. As reported by Porteiro et al. (1996), juvenile C. julis have a series of longitudinal lines (dark, yellow and one pinkish stripe) whereas juvenile $T$. pavo have a series of blue vertical stripes ending at the pectoral level, with a dark spot under the dorsal fin (Fig. 2). The juveniles observed at the cleaning stations had a mean $( \pm \mathrm{SE})$ length of $9.6 \pm 0.6 \mathrm{~cm}$ for $C$. julis and $8.3 \pm 0.4 \mathrm{~cm}$ for $T$. pavo. Observations were made from a distance of 2 to $5 \mathrm{~m}$, and began after a 2 to 5 min delay to allow the fish to become accustomed to the presence of the observer (Soares et al. 2007). Each observation lasted 30 min and was made from the water surface, with the following data recorded on plastic slates: (1) species and identity (juvenile or adult) of cleaner fish, (2) total length (TL) of each client (estimated visually to the nearest $\mathrm{cm}$ ), (3) duration of the interaction (in seconds), (4) the individual that initiated and ended the interaction between cleaner and client; (5) the number of bites the cleaner gave to each client, and (6) the number of jolts made by clients (Soares et al. 2007, 2008).

\section{Diet composition}

Collection of cleaner fish for stomach content analysis occurred at 3 different sites (Fig. 1, Sites G, J and E). In total, 60 individuals (30 C. julis and $30 \mathrm{~T}$. pavo) were collected haphazardly between 14:00 and 16:00 $\mathrm{h}$ during the same month as the cleaning observations. We also collected 5 individuals immediately following cleaning observations ( $3 \mathrm{C}$. julis and $2 \mathrm{~T}$. pavo) (Fig. 1, Site I). Each collected individual was immediately placed into a vial containing $70 \%$ alcohol and later measured (TL, $\mathrm{mm}$ ) and weighed (total weight, g). All recognizable food items were identified to the lowest possible taxonomic level and weighed (wet weight) with a precision balance (Kern EW 1500-2M; sensitivity: $0.0001 \mathrm{~g}$ ).

\section{Ectoparasite load}

Ectoparasite loads were assessed on 73 individuals belonging to 7 different littoral client (recorded as visiting the cleaning stations) and non-client (never 


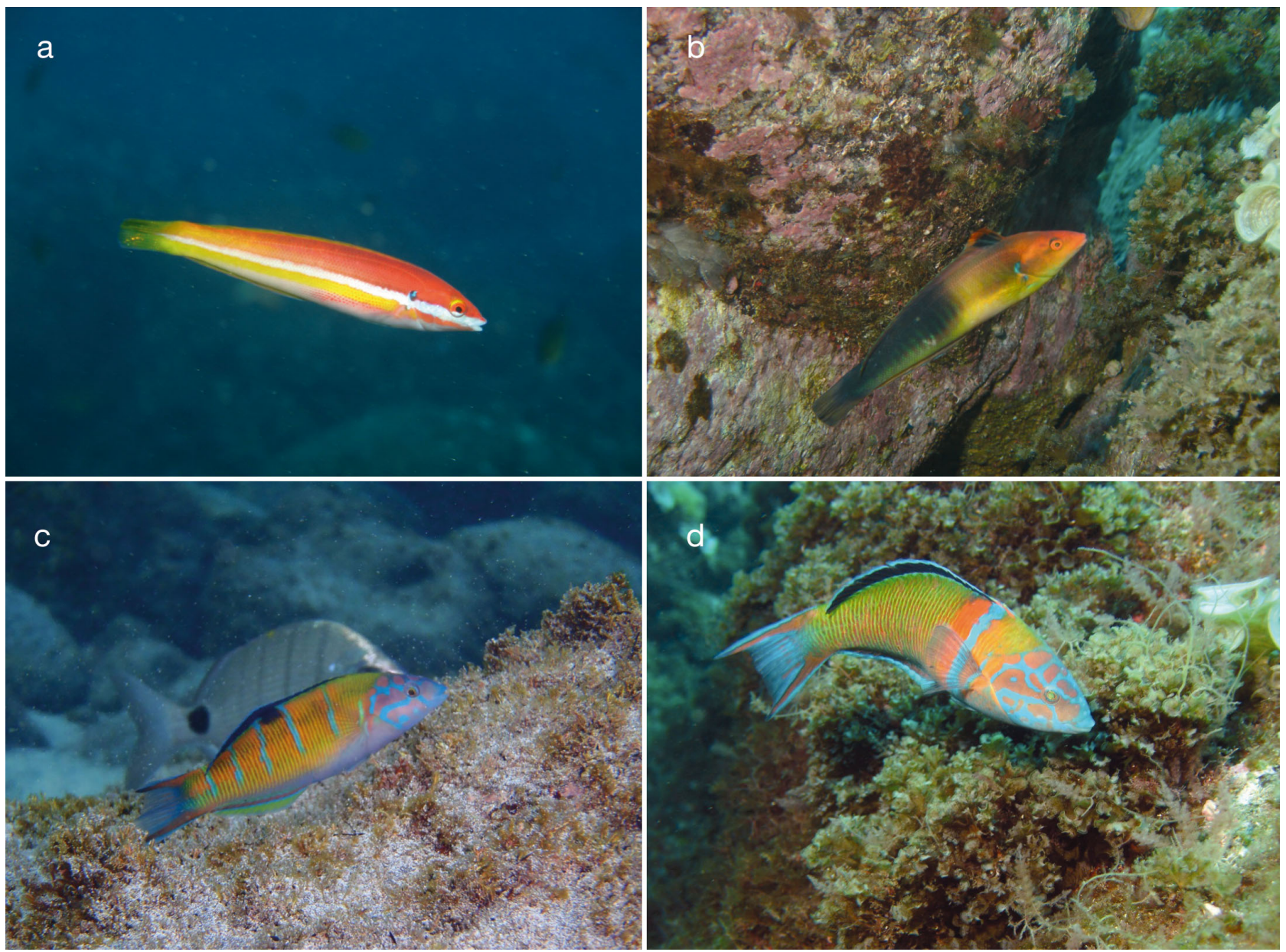

Fig. 2. Different life stages of the 2 studied species. (A) juvenile Coris julis, (B) male C. julis, (C) juvenile Thalassoma pavo, and (D) male T. pavo. Pictures provided by Island Aquatic Ecology Subgroup (IAE) of Island Biodiversity, Biogeography \& Conservation (IBBC), Centre for Ecology, Evolution and Environmental Changes (Ce3C), Departamento de Biologia, Universidade dos Açores

seen visiting the cleaning stations) species (Sites A, B, C, D, E, F, H and J, Fig. 1). Specimens were collected using a hand net (mesh size $60 \mathrm{~mm}$ ) from 7 different sites. Following capture, each fish was placed inside an individual sealed plastic bag filled with sea water. To limit fish stress and to minimize the time away from the place of capture (max. $1 \mathrm{~h}$ ), only 5 to 7 fish were collected during each sampling period (following Soares et al. 2007). On land, individual fish were removed from the bag and placed in fresh water for 10 min while the entire body surface was gently brushed with a soft-bristled paintbrush. After removing parasites, each fish was measured (TL) and transferred to seawater containers for 10 to $15 \mathrm{~min}$ to recover before being released near the capture location. The seawater inside the original plastic bag and the fresh water where the fish was brushed were then sieved through a $50 \mu \mathrm{m}$ mesh net; the resulting material was preserved in $70 \%$ alcohol. Ectoparasites were identified to family level and counted.

\section{Statistical analysis}

\section{Behavioural observations}

To determine if there were differences in client species diversity between $C$. julis and T. pavo, we first calculated the Shannon diversity index $\left(H^{\prime}\right.$; Magurran 2004) of the clients of each cleaner species. A Monte Carlo simulation (Manly 2006) was used to test the null hypothesis (i.e. no differences between cleaner species); the whole set of cleaning interactions was randomly distributed between each species of cleaner as a function of the number of 
cleaning events recorded for each, and the resulting difference between $H^{\prime}$ indices was calculated. This process was repeated 1000 times. A frequency distribution of differences obtained in the model was used to estimate the probability of obtaining a difference equal to or higher than that originally recorded. To examine relationships between the client's size and the interaction duration or number of bites given by each cleaner species to each client, we used Spearman's rank correlation, using surface area as a proxy. Finally, the hypothesis of no difference between the number of jolts per inspection time (as a correlate of cheating behaviour) by $C$. julis and T. pavo was tested using a Monte Carlo simulation. The number of jolts by clients was standardized to $60 \mathrm{~s}$ of interaction for a better comparison with other studies. Jolt events were randomly distributed between each species of cleaner, respective to the number of cleaning episodes recorded for each, and the resulting difference according to the number of jolts by each client species was recorded. This process was repeated 1000 times. The frequency distribution of differences obtained in the model was used to estimate the probability of obtaining a difference equal to or higher than that originally recorded.

\section{Diet composition}

We used numeric (IN\%), gravimetric (IG\%) and frequency of occurrence (IO\%) indices to analyse fish diet, following Hureau (1970). We used the index of relative importance (IRI) of Pinkas et al. (1971) to evaluate the relationship between various food items found in the stomachs. IRI was calculated from the 3 basics indices as follows: $\mathrm{IRI}=(\mathrm{IN} \%+\mathrm{IG} \%) \mathrm{IO} \%$. To assess differences in diet composition between $C$. julis and T. pavo, we used PERMANOVA (Anderson 2001), with species as a fixed factor on a multivariate matrix constructed using the IRI of each food item, grouped according to taxonomic group. A principal

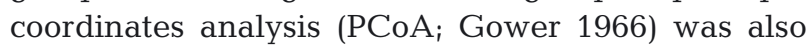
performed on the same matrix. Calculations were done using PRIMER v.6.0 (Clarke \& Gorley 2006).

\section{Fish ectoparasite load}

Kruskal-Wallis tests were used to assess differences in the number of ectoparasites among the sampled fish species, followed by (when significant) a post hoc test using the least significant difference in rank (LSD).

\section{RESULTS}

\section{Behavioural observations}

A total of 7 different fish species visited the cleaning stations (Table 1); Coris julis interacted with 6 of these and Thalassoma pavo with 4, but both predominantly interacted with the blue wrasse Symphodus caeruleus (89 and $93 \%$ of the cleaning interactions respectively; Table 1). As a consequence, no significant difference in $H^{\prime}$ was found between the 2 cleaners (Monte Carlo $\mathrm{p}=0.7$ ). Most cleaning interactions (70.9\% with C. julis and $87.0 \%$ with T. pavo) were initiated by clients adopting a specific pose, and terminated by the cleaner fish $(77.9 \%$ for $C$. julis and $85.9 \%$ for $T$. pavo). The mean $( \pm \mathrm{SE})$ duration of each interaction was $8.2 \pm 0.6 \mathrm{~s}$ for $C$. julis and $8.4 \pm 0.7 \mathrm{~s}$ for $T$. pavo. The mean number of cleaning events per 30 min was $10.7 \pm 1.3$ for $C$. julis and $12.4 \pm 2.3$ for $T$. pavo, representing a mean of $71 \pm 16.0 \mathrm{~s}$ and $76.7 \pm$ $21.9 \mathrm{~s}$ of interaction per $30 \mathrm{~min}$ of observation respectively. A significant positive relationship was found between the length of clients (TL of $C$. julis clients: $16.3 \pm 0.4 \mathrm{~cm}_{i}$ T. pavo clients: $17.0 \pm 0.4 \mathrm{~cm}$ ) and number of bites per client given by cleaners (Spearman's rank correlation, $C$. julis $\mathrm{r}=0.26, \mathrm{df}=85, \mathrm{p}=0.01 ; T$. pavo $\mathrm{r}=0.24, \mathrm{df}=85, \mathrm{p}=0.02)$. T. pavo cleaners also spent more time inspecting larger clients $(\mathrm{r}=0.45$, df $=85, \mathrm{p}<0.001)$, but the same was not found for $C$. julis $(\mathrm{r}=0.11, \mathrm{df}=85, \mathrm{p}=0.29)$. Moreover, clients inspected by $T$. pavo jolted significantly less frequently than those interacting with $C$. julis $(C$. julis 1.2 jolts $\min ^{-1}$, T. pavo 0.2 jolts $\mathrm{min}^{-1}$, Monte Carlo $\mathrm{p}=0.002$ ).

\section{Diet composition}

Overall, the most common items found in the stomachs of C. julis and T. pavo were gastropods and

Table 1. Total number $(\mathrm{N})$ and percentage of cleaning events for the 2 studied species of Azorean cleaner fish: Coris julis and Thalassoma pavo

\begin{tabular}{|lccccc|}
\hline \multirow{2}{*}{ Client species } & \multicolumn{3}{c}{ C. julis } & \multicolumn{2}{c|}{ T. pavo } \\
& N & $\%$ & N & $\%$ \\
\hline Symphodus caeruleus & 130 & 89.04 & 104 & 92.86 \\
Sparisoma cretense & 7 & 4.79 & 6 & 5.36 \\
Mullus surmuletus & 1 & 0.68 & - & - \\
Abudefduf luridus & 4 & 2.77 & - & - \\
Sarpa salpa & - & - & 1 & 0.89 \\
Coris julis & 1 & 0.68 & - & - \\
Labrus bergylta & 3 & 2.05 & 1 & 0.89 \\
\hline
\end{tabular}


crustaceans (Fig. 3a), with the latter found in higher biomass (Fig. 3b) and frequency (Fig. 3c). In general, the diet of both cleaner fish species varied significantly (PERMANOVA; df = 1, p = 0.001). The PCoA (Fig. 4) shows that this difference is due to the greater amount of crustaceans in $T$. pavo. On the other hand, $C$. julis had a more diverse diet including ectoparasites, which were found in the stomachs of
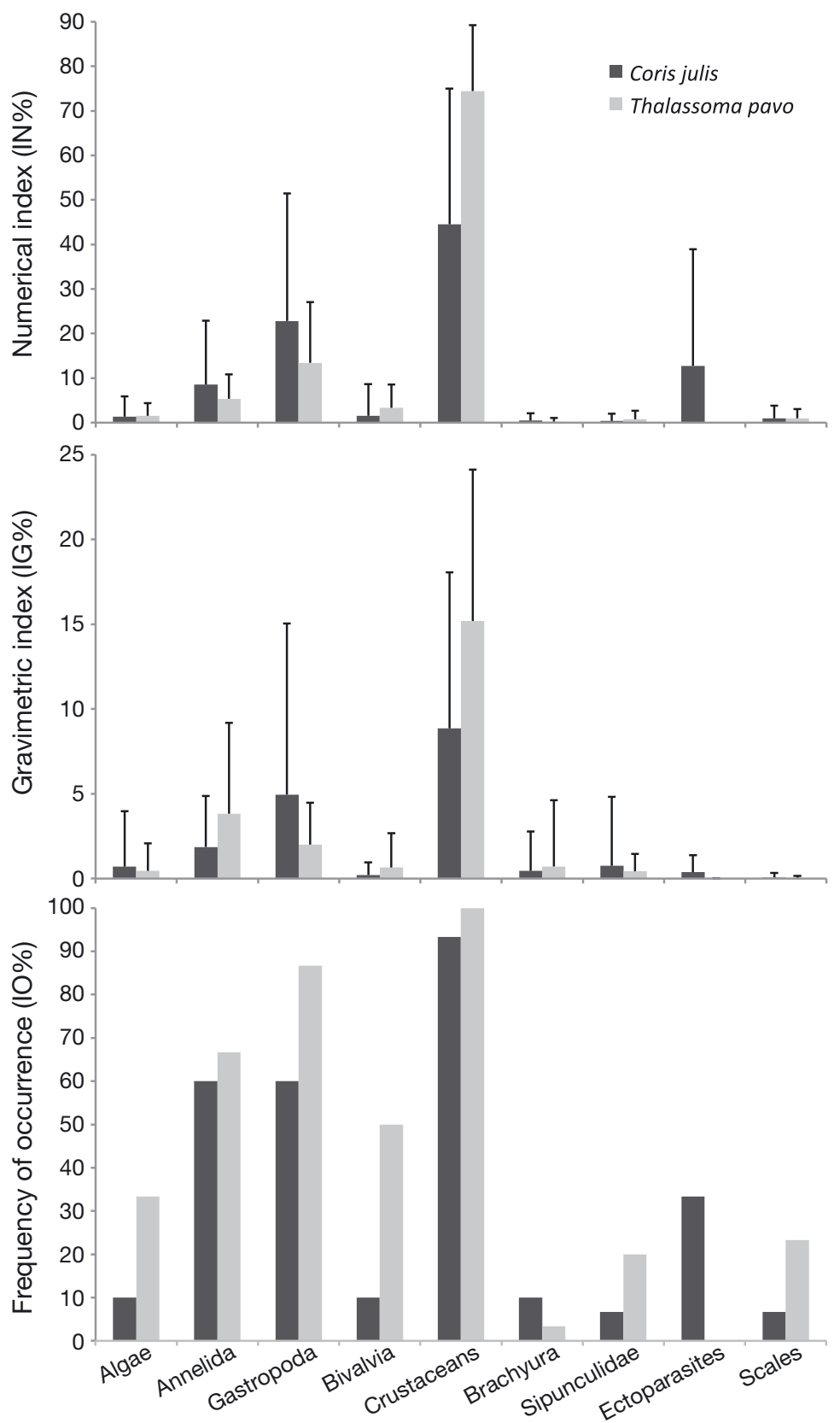

Fig. 3. Mean $( \pm \mathrm{SE})$ representation of (A) numerical index (IN\%), (B) gravimetric index (IG\%) and $(\mathrm{C})$ frequency of occurrence $(\mathrm{IO} \%)$ in the diet composition of Coris julis $(\mathrm{n}=30)$ and Thalassoma pavo $(\mathrm{n}=30)$
10 of the 30 specimens. Most of these were gnathiid isopod larvae (Gnathiidae), with only 1 caligid copepod (Caligidae). This corroborates the high amounts of gnathiid larvae found in the stomach contents of all 5 cleaner fishes collected immediately following observations of cleaning behaviour (Table 2).

\section{Ectoparasite load}

Caligid copepods and gnathiid isopods were found as external parasites of the 7 analysed littoral fish species (clients and non-clients), the first in higher numbers (Fig. 5). Overall, highly significant differences in ectoparasite loads were found between different fish species (KruskalWallis $H=19.5$, df $=6, \mathrm{p}=0.003$ ) where Mullus surmuletus and Abudefduf luridus were significantly more parasitized than Diplodus sargus (LSD post hoc test: p > 0.05). When comparing only caligid copepods, significant differences were also found among all species $(H=16.43$, df $=6$, $\mathrm{p}=0.01$; Fig. 5). For gnathiid isopods, highly significant differences were found $(H=24.24$, df $=6, \mathrm{p}=0.0004$; Fig. 5), with $S$. caeruleus and Serranus atricauda being significantly more parasitized than D. sargus (LSD post hoc test: $\mathrm{p}>0.05$ ).

\section{DISCUSSION}

Cleaner fish appear to contribute to the health of tropical fish in coastal communities (Clague et al. 2011). However, little is known about the cleaning behaviour of facultative cleaner fish species that inhabit temperate waters. This study provides new information on the cleaning activities of 2 such species: Coris julis and Thalassoma pavo. We confirmed the existence of specific territories (cleaning stations) where these temperate facultative cleaner fish species (all juveniles) received and inspected their visiting client fishes (similar to that of tropical obligate cleaner fish species), and examined the ectoparasite loads of fish species from the coastal communities of the Azores. We found that both cleaner fish species interacted with a relatively low diversity of client species. Cleaners 


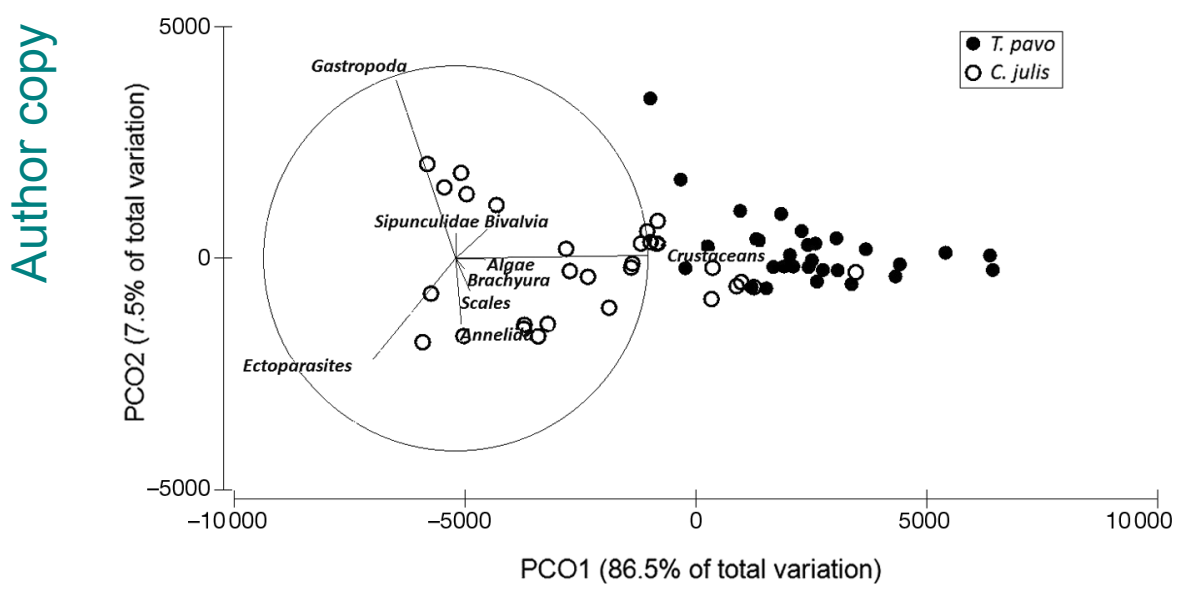

Fig. 4. Comparison of Coris julis and Thalassoma pavo diet composition (determined from 60 randomly captured fish), using principal coordinates analysis (PCoA). Results of PCoA were obtained using the index of relative importance (IRI), and show the first 2 principal coordinates which, in combination, explain $94 \%$ of the variation

appeared to glean gnathiid larvae selectively rather than caligid copepods, even though the latter were the most abundant ectoparasites found on client fish species in the Azores. Results from the present study support the hypothesis that facultative cleaner fish in temperate waters specialise on cleaning fewer species of clients (amongst those available in the reef fish community) and seem less dependent on these cleaning interactions than the obligatory cleaner fish in tropical waters (Barbu et al. 2011), which is reflected in the greater diversity of items found in these temperate cleaner fish diets. It is, however, interesting to note that the total duration spent in cleaning inspections in the present study was much lower than that reported for the cleaner fish Symphodus melanocercus in Banyuls-sur-mer (France) (Arnal \& Morand 2001, our Table 3). These differences between cleaner fish can be mostly attributed

Table 2. Mean number $( \pm \mathrm{SE})$ of items (numerical index, IN\%) in the diet composition of cleaner fish Coris julis $(\mathrm{n}=3)$ and Thalassoma pavo $(\mathrm{n}=2)$ captured following cleaning observations

\begin{tabular}{|lcc|}
\hline Items (IN\%) & C. julis & T. pavo \\
\hline Algae & $0.98 \pm 0.98$ & - \\
Annelida & $4.66 \pm 2.63$ & - \\
Gastropoda & $5.23 \pm 2.14$ & 2.05 \\
Bivalvia & - & - \\
Crustaceans & $17.42 \pm 16.30$ & 7.79 \\
Brachyura & - & 10.79 \\
Sipunculidae & - & - \\
Ectoparasites & $59.97 \pm 17.73$ & 78.55 \\
Scales & $11.74 \pm 10.09$ & 0.82 \\
\hline
\end{tabular}

to the different degree of dependency of our 2 studied species and $S$. melanocercus, the main cleaner fish in the Mediterranean Sea.

Moreover, the diversity of client species found in the present study is one of the lowest ever recorded for facultative cleaner fish species in temperate waters (Table 3 ). This may be due to the structure of the studied fish communities. Because of its isolation and narrow coastal strip, the colonization of the Azores islands by coastal organisms has been particularly constrained (Santos et al. 1995). Almada et al. (1999) reported only 48 coastal fish species in the Azores, which is much lower than the number they reported for the Marine Reserve of Arrábida (108 species) or the Mediterranean Sea (122 species). However, even with a lower number of client species compared to other studies, the number of interactions we observed in the present study was higher than that reported for the facultative cleaner fish Centrolabrus exoletus in the Marine Reserve of Arrábida (Portugal; see Table 3), which may indicate different degrees of specialisation among temperate facultative cleaner fish species.

The Azorean blue wrasse Symphodus caeruleus was the most common species at the cleaning stations. In contrast, client species such as Sparisoma cretense or Abudefduf luridus, which were reported

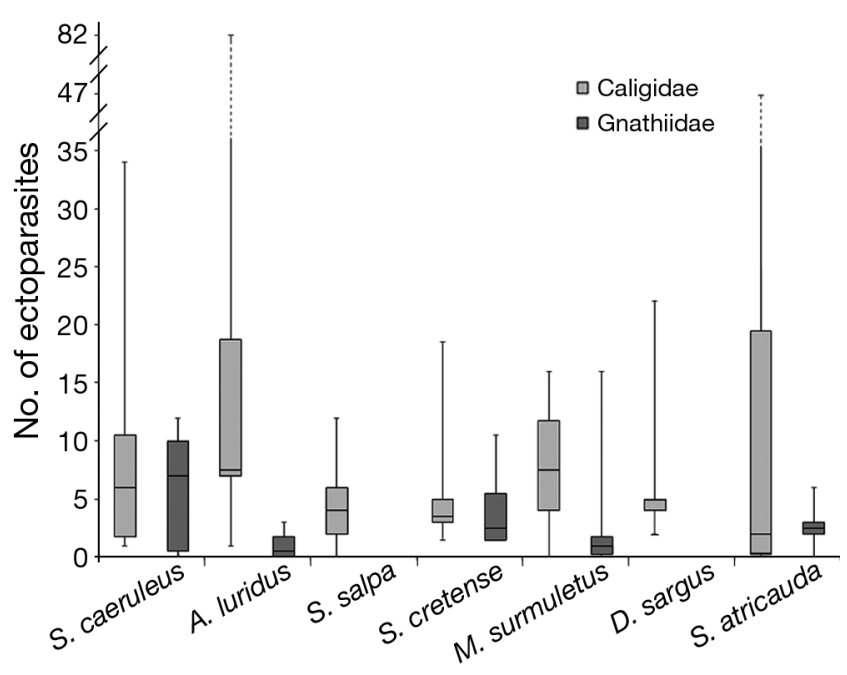

Fig. 5. Frequency of Caligidae copepods and Gnathiidae isopods found on the body surface of client species. The centre line denotes the median, the box encloses the inner 2 quartiles (25th and 75th) 
Table 3. Summary of behavioural characteristics of 9 cleaner fish species belonging to the Labridae and Gobiidae families

\begin{tabular}{|c|c|c|c|c|c|c|c|}
\hline Cleaner species & Family & $\begin{array}{l}\text { Study } \\
\text { location }\end{array}$ & $\begin{array}{l}\text { Obligate or } \\
\text { Facultative }\end{array}$ & $\begin{array}{l}\text { No. of } \\
\text { client } \\
\text { species }\end{array}$ & $\begin{array}{c}\text { No. of } \\
\text { interactions } \\
\text { per } 30 \text { min }\end{array}$ & $\begin{array}{l}\text { Total in- } \\
\text { spection time } \\
\text { per } 30 \mathrm{~min}(\mathrm{~s})\end{array}$ & References \\
\hline $\begin{array}{r}\text { Elacatinus } \\
\text { evelynae }\end{array}$ & Gobiidae & $\begin{array}{c}\text { Barbados } \\
\text { (Caribbean Sea) }\end{array}$ & Obligate & 34 & 133 & 132.9 & Whiteman \& Côté (2002) \\
\hline $\begin{array}{r}\text { Elacatinus } \\
\text { prochilos }\end{array}$ & Gobiidae & $\begin{array}{c}\text { Barbados } \\
\text { (Caribbean Sea) }\end{array}$ & Obligate & 28 & 243.6 & 243.6 & Whiteman \& Côté (2002) \\
\hline $\begin{array}{l}\text { Elacatinus cf. } \\
\text { randalli }\end{array}$ & Gobiidae & $\begin{array}{l}\text { Fernando Noronha } \\
\text { archipelago (Brazil) }\end{array}$ & Obligate & 22 & 52 & 540 & $\begin{array}{l}\text { Francini-Filho \& Sazima } \\
\text { (2008) }\end{array}$ \\
\hline $\begin{array}{l}\text { Labroides } \\
\text { dimidiatus }\end{array}$ & Labridae & $\begin{array}{l}\text { Lizard Island } \\
\text { (Australia) }\end{array}$ & Obligate & 124 & 114 & 606 & $\begin{array}{l}\text { Grutter (1996), } \\
\text { Bansemer et al. (2002) }\end{array}$ \\
\hline $\begin{array}{l}\text { Symphodus } \\
\text { melanocercus }\end{array}$ & Labridae & $\begin{array}{l}\text { Banyuls-sur-mer } \\
\text { (France) and Island } \\
\text { of Giglio (Italy) }\end{array}$ & Obligate? & 36 & 76 & 237.2 & $\begin{array}{l}\text { Galeote \& Otero (1998), } \\
\text { Arnal \& Morand (2001) }\end{array}$ \\
\hline $\begin{array}{l}\text { Thalassoma } \\
\text { noronhanum }\end{array}$ & Labridae & $\begin{array}{l}\text { Fernando Noronha } \\
\text { archipelago (Brazil) }\end{array}$ & Facultative & 19 & 57.3 & 610 & $\begin{array}{l}\text { Francini-Filho \& Sazima } \\
\text { (2008) }\end{array}$ \\
\hline $\begin{array}{l}\text { Centrolabrus } \\
\text { exoletus }\end{array}$ & Labridae & $\begin{array}{l}\text { Tarifa (Spain) and } \\
\text { Marine Reserve of } \\
\text { Arrábida (Portugal) }\end{array}$ & Facultative & 18 & 4.2 & - & $\begin{array}{l}\text { Henriques \& Almada } \\
\text { (1997), Galeote \& } \\
\text { Otero (1998) }\end{array}$ \\
\hline Coris julis & Labridae & $\begin{array}{l}\text { São Miguel Island } \\
\text { (Portugal) }\end{array}$ & Facultative & 6 & 10.7 & 72 & This study \\
\hline $\begin{array}{l}\text { Thalassoma } \\
\text { pavo }\end{array}$ & Labridae & $\begin{array}{l}\text { São Miguel Island } \\
\text { (Portugal) }\end{array}$ & Facultative & 4 & 12.4 & 76 & This study \\
\hline
\end{tabular}

as the most frequent visitors in other temperate regions (e.g. Galeote \& Otero 1998, Arnal \& Morand 2001, Quimbayo et al. 2012), were rarely observed at cleaning stations in this study. These behavioural differences could be linked to the different abundances of these species in the Azores and/or to variation in the density of fish according to depth. Indeed, the abundance of a particular fish species in a given community and their presence at cleaning stations is strongly correlated (Arnal et al. 2000, Floeter et al. 2007), and S. caeruleus is very common in the shallow water coastal communities of the Azores (Harmelin-Vivien et al. 2001, Bertoncini et al. 2010). The distribution of these species according to depth may also be a relevant factor altering the frequency of visitation to cleaning stations. For instance, A. luridus is known to occur in highest densities at depths between 11 and $27 \mathrm{~m}$ (HarmelinVivien et al. 2001), whereas our studied cleaning stations were in relatively shallow depths (between 2 and $5 \mathrm{~m}$ ). Thus, the lower client species diversity we observed may have been a result of low diversity at this site.

In general, clients adopted a specific pose to initiate an interaction, indicating that they were willing to be cleaned. Posing is known to increase the likelihood of being cleaned (Arnal \& Morand 2001). Dur- ing cleaning interactions, both C. julis and T. pavo took more bites per host when inspecting larger clients, which typically host more parasites (Poulin 2000). Cleaner cheating behaviour (assessed by client jolts) was almost negligible. Indeed, both cleaner fish species ended the interactions more often by abandoning their clients after a period of cleaning. This may reflect a depletion of food on the body surface of the clients or their preference for certain ectoparasites (i.e. gnathiids).

Overall, our data confirmed that $C$. julis and $T$. pavo are indeed micro-carnivorous with a slight tendency towards omnivory, having a preference for crustacean items (Kabasakal 2001). For fish collected haphazardly, ectoparasites (mostly gnathiid larvae and few caligid copepods) were only found in the stomachs of $C$. julis, which suggests that these are more active cleaners, and therefore more dependent on client-derived food than T. pavo. Scales were present in small quantities in the stomach contents of only a few C. julis and T. pavo, which may reflect accidental bites by the cleaners while removing ectoparasites, or perhaps some cheating events by the cleaners (Soares et al. 2009). Interestingly, all samples from the individuals (of both cleaner species) collected after cleaning observations were found to have gnathiid isopod larvae in high abundance 
(Table 2) and no caligid copepods, indicating that both species selectively removed gnathiids from the body surface of their clients. In contrast, the ectoparasites we removed from the body surface of littoral fishes during the ectoparasite sampling were dominated by caligid copepods. Caligid copepods are commonly found on colder water hosts and typically grow larger than gnathiid isopods (Whelan 2010). Gnathiids, on the other hand, have mainly been reported on tropical hosts (Grutter \& Poulin 1998). However, we found that $C$. julis and T. pavo consumed more gnathiid isopods than caligids, a preference also shown by other cleaner species in both tropical (e.g. Grutter 2002, Soares et al. 2010) and temperate waters (e.g. Galeote \& Otero 1998, Arnal \& Morand 2001). This could be due to the fact that gnathiid isopods are likely more nutritious to the cleaner, as their guts typically contain a relatively large volume of the blood and lymphatic fluids of their hosts (Wägele 1988). Gnathiids are putatively some of the most harmful parasites of reef fish (Lester \& Roubal 1995), causing significant energy losses (Bunkley-Williams \& Williams 1998). Thus, differential susceptibility to gnathiid parasitism possibly explains the observed differences in visits to the cleaning stations. Indeed, $S$. caeruleus was simultaneously the most highly gnathiid-parasitized client and the species that interacted most with cleaners.

Our study is the first to demonstrate that a mutualistic relationship exists between cleaner fish and their clients in the Azores, where juvenile C. julis and T. pavo actively and selectively inspect and remove ectoparasites from their clients. Thus, they appear to provide a beneficial service which may potentially contribute to better overall client body condition (Ros et al. 2011) by lowering ectoparasite levels. Further work is necessary to examine the impact of these cleaner fish - not solely to the Azorean fish community, but also in other locations where $C$. julis occurs, such as the Mediterranean Sea.

Acknowledgements. We thank Ruben Couto, Nuno Álvaro and Afonso Prestes for support in the field and Gustavo Martins for help with the statistical analysis. This study was partially financed by Fundação para a Ciência e Tecnologia (FCT, grant PTDC/MAR/105276/2008 given to M.C.S.). M.C.S. was supported by the Project 'Genomics and Evolutionary Biology', co-financed by North Portugal Regional Operational Programme 2007/2013 (ON.2-O Novo Norte), under the National Strategic Reference Framework (NSRF), through the European Regional Development Fund (ERDF). This research was also partially supported by the European Regional Development Fund (ERDF) through the COMPETE-Operational Competitiveness Programme and national funds through FCT-Foundation for Science and Technology, under the project 'PEst-C/MAR/LA0015/2011.

\section{LITERATURE CITED}

Almada VC, Gonçalves EJ, Henriques M (1999) Ecology and behaviour of reef fishes in the temperate north-eastern Atlantic and adjacent waters. In: Almada VC, Oliveira $\mathrm{RF}$, Gonçalves EJ (eds) Behaviour and conservation of littoral fishes. ISPA, Lisbon, p 33-68

Anderson MJ (2001) A new method for non-parametric multivariate analysis of variance. Austral Ecol 26:32-46

Arnal C, Morand S (2001) Importance of ectoparasites and mucus in cleaning interactions in the Mediterranean cleaner wrasse Symphodus melanocercus. Mar Biol 138: 777-784

Arnal C, Côté IM, Sasal P, Morand S (2000) Cleaner-client interactions on a Caribbean reef: influence of correlates of parasitism. Behav Ecol Sociobiol 47:353-358

Ayling AM, Grace RV (1971) Cleaning symbiosis among New Zealand fishes. N Z J Mar Freshw Res 5:205-218

Bansemer C, Grutter AS, Poulin R (2002) Geographic variation in the behaviour of the cleaner fish Labroides dimidiatus (Labridae). Ethology 108:353-366

Barber I, Hoare D, Krause J (2000) The effects of parasites on fish behaviour: a review and evolutionary perspective. Rev Fish Biol Fish 10:131-165

- Barbu L, Guinand C, Bergmüller R, Alvarez N, Bshary R (2011) Cleaning wrasse species vary with respect to dependency on the mutualism and behavioural adaptations in interactions. Anim Behav 82:1067-1074

Bertoncini AA, Machado LF, Barreiros JP, Hostim-Silva M, Verani JR (2009) Cleaning activity among Labridae in the Azores: the rainbow wrasse Coris julis and the Azorean blue wrasse Centrolabrus caeruleus. J Mar Biol Assoc UK 89:859-861

Bertoncini AA, Machado LF, Barreiros JP, Hostim-Silva M, Verani JR (2010) Rocky reef fish community structure in two Azorean islands (Portugal) central North Atlantic. J Mar Biol Assoc UK 90:1353-1362

Binning SA, Roche DG, Layton C (2013) Ectoparasites increase swimming costs in a coral reef fish. Biol Lett 9: 20120927

Bshary R, Grutter AS (2005) Punishment and partner switching cause cooperative behaviour in a cleaning mutualism. Biol Lett 1:396-399

Bunkley-Williams L, Williams EH (1998) Isopods associated with fishes: a synopsis and corrections. J Parasitol 84: 893-896

Clague GE, Cheney KL, Goldizen AW, McCormick MI, Waldie PA, Grutter AS (2011) Long-term cleaner fish presence affects growth of a coral reef fish. Biol Lett 7 : 863-865

Clarke KR, Gorley RN (2006) PRIMER v6: user manual/tutorial. PRIMER-E, Plymouth

Côté IM (2000) Evolution and ecology of cleaning symbioses in the sea. Oceanogr Mar Biol Annu Rev 38:311-355

Côté IM, Soares MC (2011) Gobies as cleaners. In: Patzner RA, Van Tassell JL, Kovacic M, Kapoor BG (eds) The biology of gobies. Taylor \& Francis, Enfield, NH, p 531-557

Cushman JH, Beattie AJ (1991) Mutualisms: assessing the benefits to hosts and visitors. Trends Ecol Evol 6:193-195

Fischer ST, Patzner RA, Müller CHG, Winkler HM (2007) Studies on the ichthyofauna of the coastal waters of Ibiza (Balearic Islands, Spain). Rostock Meeresbiol Beitr 18: $30-62$

> Floeter SR, Vázquez DP, Grutter AS (2007) The macroecol- 
ogy of marine cleaning mutualisms. J Anim Ecol 76: 105-111

- Francini-Filho RB, Sazima I (2008) A comparative study of cleaning activity of two reef fishes at Fernando de Noronha Archipelago, tropical West Atlantic. Environ Biol Fishes 83:213-220

Galeote MD, Otero JG (1998) Cleaning behaviour of rock cook, Centrolabrus exoletus (Labridae) in Tarifa (Gibraltar Strait Area). Cybium 22:57-68

$>$ Gower JC (1966) Some distance properties of latent root and vector methods used in multivariate analysis. Biometrika 53:325-338

- Grutter AS (1996) Parasite removal rates by the cleaner wrasse Labroides dimidiatus. Mar Ecol Prog Ser 130: $61-70$

Grutter AS (2002) Cleaning symbioses from the parasite's perspective. Parasitology 124:65-81

> Grutter A, Bshary R (2003) Cleaner fish prefer client mucus: support for partner control mechanisms in cleaning interactions. Proc R Soc Lond B 270(Supp 2):S242-S244

Grutter AS, Lester R (2002) Cleaner fish Labroides dimidiatus reduce 'temporary' parasitic corallanid isopods on the coral reef fish Hemigymnus melapterus. Mar Ecol Prog Ser 234:247-255

Grutter AS, Poulin R (1998) Cleaning of coral reef fishes by the wrasse Labroides dimidiatus: ecological and phylogenetic influences. Copeia 1998:120-127

Guidetti P (2001) Population dynamics and post-settlement mortality of the ornate wrasse, Thalassoma pavo, in the Tyrrhenian Sea (western Mediterranean). Ital J Zool 68: 75-78

Guidetti P, D'Ambrosio P (2004) Spatial variability in the distribution patterns of Coris julis and Thalassoma pavo (Pisces, Labridae) along the south-eastern Apulian coast. Thalassia Salent 27:81-90

Harmelin-Vivien ML, Harmelin JG, Almeida AJ (2001) Structure of fish assemblages on coastal rocky shores of the Azores. Bol Mus Munic Funchal 6:127-138

Henriques M, Almada VC (1997) Relative importance of cleaning behaviour in Centrolabrus exoletus and other wrasses at Arrábida, Portugal. J Mar Biol Assoc UK 77 : 891-898

Hureau JC (1970) Biologie comparée de quelques poissons antarctiques (Nototheniidae). Bull Inst Oceanogr 68: $1-244$

Kabasakal H (2001) Description of the feeding morphology and the food habits of four sympatric labrids (Perciformes, Labridae) from south-eastern Aegean Sea, Turkey. Neth J Zool 51:439-455

Lester RJG, Roubal FR (1995) Phylum Arthropoda. Isopoda: Cymotholdae. In: Woo PTK (ed) Fish diseases and disorders, Vol 1: protozoan and metazoan infections. CAB International, Wallingford, p 550-561

Limbaugh C (1961) Cleaning symbiosis. Sci Am 205:42-49

Magurran AE (2004) Measuring biological diversity. Blackwell Publishing, Malden, MA

Manly BFJ (2006) Randomization, bootstrap and Monte Carlo methods in biology, 3rd edn. Chapman \& Hall, London

Moosleitner VH (1980) Putzerfische und -garnelen im Mittelmeer. Zool Anz 205:219-240

Muus BJ, Nielsen JG (1999) Sea fish. Scandinavian fishing yearbook. Hedehusene

Pinkas L, Oliphant MS, Iverson ILK (1971) Food habits of albacore, bluefin tuna, and bonito in California waters.
Calif Dep Fish Game Fish Bull 152:1-105

Porteiro FM, Barreiros JP, Santos RS (1996) Wrasses (Teleostei: Labridae) of the Azores. Arquipel Life Mar Sci 14A:23-40

Poulin R (2000) Variation in the intraspecific relationship between fish length and intensity of parasitic infection: biological and statistical causes. J Fish Biol 56:123-137

Quignard JP, Pras A (1986) Labridae. In: P Whitehead PJP, Bauchot ML, Hureau JC, Nielsen J, Tortonese E (eds) Fishes of the north-eastern Atlantic and the Mediterranean, Vol 2. UNESCO, Paris, p 919-942

Quimbayo JP, Floeter SR, Noguchi R, Rangel CA and others (2012) Cleaning mutualism in Santa Luzia (Cape Verde Archipelago) and São Tomé Islands, tropical eastern Atlantic. Mar Biodivers Rec 5:e118

Randall JE, Allen GR, Steene RC (1990) Fishes of the Great Barrier Reef and Coral Sea. University of Hawaii Press, Honolulu, HI

Ros AF, Lusa J, Meyer M, Soares M, Oliveira RF, Brossard M, Bshary R (2011) Does access to the bluestreak cleaner wrasse Labroides dimidiatus affect indicators of stress and health in resident reef fishes in the Red Sea? Horm Behav 59:151-158

Santos RS, Hawkins SJ, Monteiro LR, Alves M, Isidro EJ (1995) Marine research, resources and conservation in the Azores. Aquat Conserv 5:311-354

Schneider W (1990) FAO species identification sheets for fishery purposes. Field guide to the commercial marine resources of the Gulf of Guinea. FAO, Rome

Soares MC, Cardoso SC, Côté IM (2007) Client preferences by Caribbean cleaning gobies: food, safety or something else? Behav Ecol Sociobiol 61:1015-1022

Soares MC, Bshary R, Cardoso SC, Côté IM (2008) The meaning of jolts by fish clients of cleaning gobies. Ethology 114:209-214

Soares MC, Bshary R, Côté IM (2009) Cleaning in pairs enhances honesty in male cleaning gobies. Behav Ecol 20:1343-1347

Soares MC, Côté IM, Cardoso SC, Oliveira RF, Bshary R (2010) Caribbean cleaning gobies prefer client ectoparasites over mucus. Ethology 116:1244-1248

- Soares MC, Cardoso SC, Nicolet KJ, Côté IM, Bshary R (2013) Indo-Pacific parrotfish exert partner choice in interactions with cleanerfish but Caribbean parrotfish do not. Anim Behav 86:611-615

Van Tassell JL, Brito A, Bortone SA (1994) Cleaning behavior among marine fishes and invertebrates in the Canary Islands. Cybium 18:117-127

Wägele JW (1988) Aspects of the life-cycle of the Antarctic fish parasite Gnathia calva Vanhöffen (Crustacea: Isopoda). Polar Biol 8:287-291

Waldie PA, Blomberg SP, Cheney KL, Goldizen AW, Grutter AS (2011) Long-term effects of the cleaner fish Labroides dimidiatus on coral reef fish communities. PLoS One 24: e21201

Whelan K (2010) A review of the impacts of the salmon louse, Lepeophtheirus salmonis (Krøyer, 1837) on wild salmonids. Atlantic Salmon Trust, Perth

Whiteman EA, Côté IM (2002) Cleaning activity of two Caribbean cleaning gobies: intra and interspecific comparisons. J Fish Biol 60:1443-1458

Zander CD, Sötje I (2002) Seasonal and geographical differences in cleaner fish activity in the Mediterranean Sea. J Helgol Mar Res 55:232-241 